DOI https://doi.org/10.36059/978-966-397-158-2/225-242

\title{
SYMBOLIC ATTRIBUTION OF STATE SOVEREIGNTY AS A FACTOR OF POLITICAL TRANSIT: THE POST-SOVIET EXPERIENCE
}

\section{Mamontova E. V.}

\section{INTRODUCTION}

In the context of the generally accepted understanding of political transit as a state of change in the characteristics of the political system in the transition from one political regime to another, the vector of democratic transit is defined by the coordinates «authoritarianism - democracy». However, as practice shows, democracy is not a necessary result of this process. Among the reasons for this situation are almost all the basic theoretical models of the transition of the state from authoritarian to democratic political regime (structural (G. Almond, S. Verba, R. Dahl, R. Inglihart, D. Rastow, R. Rose), procedural (G.O'Donnel, F. Schmitter, H. Linz, A. Stepan), integrative (J. Mahoney, R. Snyder), synthetic (S. Larsen, A. Melville), called slowing down of the transition in the phase of consolidation of democratic values at the level of the cultural code. In order for democratic development to become irreversible, not only political decision-making, awareness and perception of democratic rules and procedures, the establishment of democratic institutions, but also the consolidation of democratic values, are needed (D. Rastow, A. Przeworski, G. O'Donnell, F. Schmitter, etc.). The latter is influenced by national and cultural-value factors, among which symbolism occupies an important place.

History has repeatedly proved that systemic transformations always affect the symbolic sphere of society. Typically, the first indicator of these transformations is state symbolism, which, by fixing changes in the nationalstate symbolic space, consolidates state sovereignty. That is why one of the first steps to follow the act of declaration of independence is to recreate it in new symbols - attributes of state sovereignty. This provision also demonstrates the state-building experience of post-Soviet countries.

In this connection, it should be noted that as a backbone historical process of becoming a political organization of society, state formation is a multifaceted phenomenon of ontological order that covers all spheres of social life. Hence, the implementation of a state-building project requires the 
involvement of all possible resources, including non-institutional nature. Among the resources of the latter category, one of the most powerful is the symbolic resource, which we propose to define as a multifaceted tool, based on symbolic complexes formed according to their structural and functional load, which they carry in the process of state self-determination in the symbolic space of politics.

Historians are well aware that in the struggle for independence, symbols always play a huge role in proclaiming sovereignty as statehood. Under the state symbol, we suggest to understand a special, historically formed, distinctive sign of a state, which is embodied in its sovereignty and carries an ideological burden, established by the constitution or a separate law. It should be noted that each of the symbols of state sovereignty - the flag, the emblem, the motto and the anthem - fulfill their special mission, and together they create a coherent semantic text interwoven with the discourse of politics.

So, the flag is historically the first state symbol and, thanks to the totemic nature and abstract nature of semantics, acts as the nucleus of the civic symbolosphere and is the constituent structure of the state symbolic space. The peculiarities of the emblem as a state symbol are conditioned by the fact that it is a sign of institutional attribution. Hence the emblem is, above all, a symbol of official power in the country. The state motto, which became part of state symbols as a result of the transformation of dynastic coats of arms into state (imperial), articulates the mission of the state and its goals in a concise form. The State Anthem, in turn, contains a message in an external communicative environment that contains an annotated text about the worldview universals of the nation.

Review of state symbols in the context of their ontological status, historical origin and semantic load, indicates that as the most specified ideological manifesto of universal principles of national and statesman's outlook, the anthem complements the metaphorical and interpretative nature of the abstract flag and emblem symbols and together, which acquires systematic properties. This symbolic complex of attribution (hereinafter SCA), being a symbolic formation, is transformed with changes of spiritual priorities, values of society and reflects systemic transformations in its political sphere.

All this was fully evidenced by the history of independence of the postSoviet countries.

Let's try to explore the main stages of the formation of symbolic sovereignty in young countries that emerged in the former USSR, and to identify and correlate the political and sociocultural determinants of social 
development on the basis of identifying and comparing their characteristic features. The solution to this problem will enable us to achieve the goal of our research, namely to reveal the peculiarities of the symbolic attribution of state sovereignty as a factor of political transit and to evaluate its statebuilding potential.

\section{Symbolic representation of democratic transit: from transitional societies to consolidated democracy (for example, the Baltic countries, the Caucasus and the Caucasus, Moldova)}

The first acts that gained symbolic meaning on the difficult path of free political self-determination of the new countries and its constitutional consolidation were the Declarations of Sovereignty and Independence brief, meaningful documents that outlined the basic principles that characterized their independence and sovereignty and, at the same time, symbolized peoples' desire to enter the circle of democratic countries of the world. The further trajectory of the state-making process was determined, in our opinion, by such significant events in its development as the change of the official name of the country, the acquisition of new symbols of state sovereignty, the adoption of the Constitution.

At the forefront of these changes were the Baltic countries, which were the first among the Soviet republics to abandon communist symbolism.

Leading among them was Lithuania, which was able not only to restore and legalize historical symbolism, but also to consolidate it in the legal field of the USSR, giving it state status. On November 18, 1988, the Supreme Soviet of the Lithuanian SSR adopted a law "On Amendments to Articles 168 and 169 of the Constitution of the Lithuanian SSR», according to which the State Flag of the republic was proclaimed «a State Flag consisting of three equal horizontal stripes: upper - yellow, medium - green, middle - green, lower - red» ${ }^{1}$. A new norm for the size of the State Flag was also symbolic. The Soviet flag etiquette in force at the time suggested that while the flags of the USSR and the republics were being used at the same time, the latter could not be larger than the Union flag (it had a 1:2 ratio). However, it was expected that the newly proclaimed republican flag would become an equal State Flag.

Article 169 of the Constitution of the Lithuanian SSR approved the «National song» of V. Kudirka as the State Anthem. On March 11, 1990, on the day of the proclamation of the Act on the Restoration of Lithuanian Independence, the Parliament of the Republic adopted a law «On State

${ }^{1}$ Про изменение статей 168 та 169 Конституции Литовськой ССР: Закон Литовской РСР от 18.11.1988 г. Советская Литва. 1990. 19 ноября. 
Name and Coat of Arms», which approved the new name of the country and approved as the official State Emblem of the Republic of Lithuania an image of Vitis - a rider in the armor, considered a heraldic sign of the Lithuanian territories. However, the reference images of the coat of arms and its description were later adopted by a separate law «On the State Emblem of Lithuania» of April 10, 1990. The systematic transformations were evidenced by the re-approval of the national tricolor by the Law «On the State Flag of Lithuania», adopted by the Verkhovna Rada on June 26, 1991.

In a similar scenario, there were changes in the attribute complex of Estonia. In general, the model of the acquisition of symbolic sovereignty of the republic was defined by the coordinates: «from the legislative consolidation of national symbols to the legalization of symbols of the statehood of the pre-Soviet period» and continued from the fall of 1988, when the Decree of the Presidium of the Supreme Soviet of the Estonian SSR of October 20, 1988 «On Approval of the Regulation on the Procedure for the Use of the National Symbols of Estonia» the national blue-blackwhite flag was renewed and national cornflower and swallow were designated by the end of 1990).

A few years later Lithuania and Estonia decided to attribute symbolically their independence to Latvia. On February 15, 1990 the Laws «On Amendments to the Constitution of the Latvian SSR», «On the State Emblem», «On the State Flag» and «On the State Anthem» returned the status of state one to pre-war symbols of the country. The State Flag again became a carmine-red cloth with a longitudinal white stripe in the middle.

With the introduction of the presidency institute in the state, which was renewed in the summer of 1993 with the Constitution of 1922, the use of the pre-war presidential flag (standard) was restored.).

Thus, the formation of the symbolic complex of attribution of the Baltic countries was based on the return and legalization of the heraldic system of the pre-Soviet interwar period with a final and unanimous rejection of communist symbolism and can be regarded as a progressive process, organically woven into transformational changes of a systemic nature. And today, relying on the ideology of the Soviet occupation, the Baltic countries often use symbolism to solve all kinds of domestic and foreign policy problems. Where the language of diplomacy does not work, the techniques of «symbolic wars» that we have repeatedly witnessed in recent years have been effectively used.

Thus, as the experience of the symbolic self-determination of the state sovereignty of the Baltic countries testifies, the dramaturgy of the formation of the symbolic complex of attribution is clearly linked to the political and sociocultural determinants of social development. Thus, in the countries of the region where democratic political regimes were formed today, in the process of independence, a radical reformation of the symbolic space took 
place on the basis of the return to the historical symbols of the statehood of the pre-Soviet model. Given that this process took place in a situation of absolute civic support, it can be argued that in societies dominated by (or gravitating to) the democratic system of values in the processes of statebuilding, national symbolism becomes the subject of the political process. Performing the traditional political symbolism functions of mobilization and integration, national symbolism becomes a real catalyst for political transformations.

The process of symbolic attribution of the state independence of the Soviet republics of the Caucasus and the Transcaucasia was somewhat similar. However, unlike the Baltic countries, whose symbolic selfdetermination was the unconditional and complete resuscitation of the symbolism of the pre-Soviet period, the specificity of the political history of the Caucasian territories, which resulted in the absence of a systematic heraldic tradition among the peoples of the region, determined the independence of the governed people and their independence to the arsenal of national historical symbolism.

Thus, the symbolic self-expression of Armenia, which, with the restoration after its six-hundred-year break of statehood, turned to the arsenal of historical symbolism, is based on symbols that date back to the times of ancient kingdoms. The first attribute of its national selfdetermination was the flag enshrined in the Law of August 24, 1990: a rectangular panel with three equal horizontal stripes - red, blue and orange (1:2 ratio of width and length of the flag). In the popular interpretation, the red flag means bloodshed in the struggle for independence, blue means the unchanging nature of the earth, and orange means the industriousness of the Armenian people ${ }^{2}$.

On July 1, 1991, a resolution of the Verkhovna Rada of the Republic approved the new State Anthem of Armenia. The anthem of the Republic of Armenia from 1918 to 1920 (the so-called first republic) was taken as its basis). On September 21, that year, a nationwide referendum was held, which resulted in the decision to withdraw from the USSR, and September 23 has been recognized as the official Independence Day.

The acquisition of state sovereignty required its immediate consolidation in the heraldic space. The result of the public discussion was the resolution of the Supreme Council of Armenia of April 19, 1992 approving the State Emblem. Its ideology is based on the national symbols of the Armenian people: in the center on the shield is the two-peak Mount Ararat with Noah's Ark, at the foot of the mountain are the silver waves of Van Lake; they are surrounded by the arms of four royal dynasties - Artashesid, Arshakuni,

${ }^{2}$ Гречило А. Герби новопосталих держав. Пам'ятки Украӥни: Історія та культура. 2001. № 2. C. 163. 
Bagratuni and Rubinians (Cilicia); the shield is supported by an eagle and a lion - symbols of the power of spirit and power, and under the shield depicts a sword, a broken chain (symbols of the people's struggle for freedom and independence), a feather, ears (embodiment of creative talent, peacefulness) and a ribbon in national colors ${ }^{3}$.

Thus, the symbolic attribution of Armenian sovereignty came about with wide public resonance and ran along the trajectory: «flag - anthem declaration of independence - coat of arms - Constitution», which allows to speak about the subjectivity of state symbols as an agent of political transit.

In almost similar scenarios, the symbolic spaces of Georgia and Azerbaijan were reformatted. The post-Soviet symbolic creation of the 1990s in these countries relied on centuries-old historical and national traditions and was inspired by the heraldic aesthetics of the democratic republics of 1918-1920.

In general, the processes of symbolic attribution of state sovereignty of the former Soviet republics of the Caucasus region can be characterized as occurring against the backdrop of lively civic debate. Although, in most cases, the introduction of new symbols did not encourage political transformation, but only anchored them in the civic symbolism of the country.

The national symbolism in the processes of state self-determination of the people of Moldova played a fundamentally different role. The period between the proclamation of sovereignty and the adoption of the Declaration of Independence (June 23, 1990 - August 27, 1991) became the defining and intense one on the path of rebuilding the national symbolic space of the republic. Chronologically, this process is marked by such moments as the Latinization of the Moldovan alphabet (August 31, 1989), the change of flag (April 27, 1990), the proclamation of sovereignty (June 23, 1990), the introduction of the post of president (September 3, 1990), adoption of the state emblem (November 3,1990), change of the official name of the state (May 23, 1991), declaration of independence (August 27, 1991). As we can see, the starting point in the process of systemic transformation was the adoption of laws on August 31, 1989 «On the status of the state language of the Moldavian SSR» and «On the return of the Moldovan language to Latin graphics» by the supreme legislative body of the Moldavian SSR, which granted the status of the state language to Romanian and enshrined the return of its Latinized version.

The proclamation of state sovereignty, which took place on June 23, 1990, was also preceded by the most important, in the context of symbolic self-determination of statehood, the decision to adopt a new state flag. On April 27, 1990 the Supreme Council of the Moldavian SSR adopted the Law

\footnotetext{
${ }^{3}$ Цугунян М. 3 історії герба та прапора республіки Вірменії. Знак. 1994. № 7. С. 9.
} 
on the State Flag - blue-yellow-red tricolor. The Regulation on the State Flag, approved by the Decree of the Parliament No. 17 - XII of May 12, 1990, reads: «The State Flag of the Republic of Moldova - tricolor - is the official symbol of the Republic of Moldova. It symbolizes the past, present and future of the Moldovan state, reflects its democratic beginnings, historical tradition ${ }^{4}$.

An important part of the process of preparation and declaration of independence was the restoration of traditional national symbols. Thus, on September 3, 1990, two months after the new flag was adopted, simultaneously with the establishment of the post of President of the country (Decree of the Supreme Council of the Moldovan SSR No. 251 - XII of September 3, 1990), the Supreme Council of the MSSR chooses as an emblem the ancient Moldavian symbol - the head of the tour'. The Regulation on the State Emblem of the Republic of Moldova, approved by the Law of November 3, 1990, states: «The State Emblem of the Republic of Moldova is a horizontal cross-section, in the upper part of which is a red field, in the lower part - blue. The center of the shield depicts the head of a bison, between the horns of which is an eight-ray star» ${ }^{6}$.

Further changes in the civic symbolism of the republic took place on May 23, 1991, when the name of the country was officially changed by Law of the Supreme Council of the MSSR No. 589-XII. The Soviet Socialist Republic of Moldova was renamed the Republic of Moldova.

In our view, Moldova's declaration of independence, which took place in response to the August events of 1991, can be regarded as the result of processes of national and state self-determination, an integral part of which was the reformatting of its symbolic space.

On August 27, 1991, the Parliament of the Republic adopted the Declaration of Independence of the Republic of Moldova. This date was declared a national holiday - Moldova Independence Day. In 2003, it was renamed Republic Day.

With the adoption of the Constitution of the Republic of Moldova on 29 July 1994, the status of national symbols was finally affixed to the flag, coat of arms and anthem (Article 12). However, it should be noted that the State Anthem was introduced the last among the elements of the symbolic

${ }^{4}$ Государсвенный флаг Республики Молдова: Положение о Государственном флаге, утвержденное Постановлением Парламента №17-XII от 12 мая 1990 года). Президентура Республики Молдова: веб-сайm. URL: http://www.president.md/simb.php?lang=rus.

${ }^{5}$ Про Державний герб Республики Молдова: Закон РМ № 337-XII от 3 ноября 1990 г. Президентура Республики Молдова: веб-сайт. URL: http://www.president.md/ simb.php?lang=rus.

${ }^{6}$ Положение о Государственном гербе, утвержденное Законом Республики Молдова № 337-XII от 3 ноября 1990 года. Президентура Республики Молдова: веб-сайт. URL: http://www.president.md/simb.php?lang=rus. 
complex of attribution in the symbolic space of the country. By a law of July 22, 1995, the song «Limba noastră $»$ on the poems of Alexei Mateevich (1.2.5.8.12. Stanza) and the music of Alexander Christa in arrangement by Valentin Dingy was officially approved as anthem ${ }^{7}$.

Thus, the example of Moldova proves that the process of symbolic attribution of state sovereignty can become a real locomotive of systemic transformations in the political and spiritual sphere of society and contribute to the political transit to the democratic channel.

\section{Specificity of symbolic attribution of state sovereignty in Central Asian countries as a marker of consolidation of authoritarian tradition}

The attribution of independence in the Central Asian and Kazakhstan republics was somewhat different. First of all, in the symbols of state sovereignty, the traditional Muslim symbolism for these territories has received a new, albeit hidden, sound.

Given that the tradition of symbolically presenting subjects of sociopolitical relations, such as the European heraldic sign systems, has not historically been formed in the countries of the Islamic circle, the history of heraldry in the post-Soviet region de facto begins in Soviet times. After all, the final formation of nation-states in this territory in modern borders dates back to the 1920's. That is why, faced with the need for symbolic selfdetermination of state sovereignty, the new states of Central Asia, without being able to turn to historical models, chose the path of conceptual symbolization «from a blank sheet.» The most significant in this aspect was the experience of Uzbekistan.

Having proclaimed its sovereignty on August 31, 1991, the Republic of Uzbekistan actively began to create its own symbolic complex of attribution. On November 18, 1991, the Supreme Council of the Republic of Uzbekistan approved a new state flag following the results of the competition ${ }^{8}$. The green-blue-white palette and the heraldic signs on the flag are interpreted by the official Uzbek heralds as follows: blue is a symbol of eternal sky and water; white - peace, wishes for a happy journey, purity of thoughts and actions; green is the color of nature, new life and fertility; red means vitality. The moon is interpreted as a sign of independence, the stars as a symbol of a cloudless sky, and their number is associated with historical traditions and the ancient solar calendar ${ }^{9}$. However, it is indisputable that under this secular

${ }^{7}$ О Государственном гимне Республики Молдова: Закон РМ № 571-XIII от 22 июля 1995 года. Президентура Республики Молдова: веб-сайт. URL: http://www.president.md/ simb.php?lang=rus.

${ }^{8}$ О Государственном флаге Республики Узбекистан: Закон Республики Узбекистан. Правда Востока. 1991. 27 ноября. С. 1.

${ }^{9}$ Гречило А. Символи нових незалежних держав. Пам'ятки Украӥни: Iсторія та культура. 2001. № 4. С. 135-141. 
and sufficiently poetic description are hidden basic symbols traditional for the Muslim world, such as green color, stars, new moon, etc.

On June 2, 1992, the Parliament of the Republic approved the State Emblem of the RU. Its semantics are in harmony with the State Flag palette and are based on traditional Uzbek culture symbols (humorous bird with wings that are considered the embodiment of the idea of happiness and love, cotton, wheat) and at the same time include Muslim ornamentals (octagon, crescent, star). On December 10 of the same year, a separate law approved the anthem of the RU: «Get up, my free country.» However, despite the efforts of the official experts to mark the new attributes of Uzbekistan's sovereignty as original, the genetic connection of the visual decision of the new state symbols with the Soviet heraldic stylistics is striking.

In general, it should be noted that the symbolic process in this country was not actualized in the broad civil debate, but passed under the patronage of the state, creating a model more characteristic of the political culture of the Soviet society. New symbols of independence, without becoming subjects of political discourse, played the role of signs that only fixed the status quo.

Similar scenarios of symbolic consolidation of statehood, the format of which can be defined as «symbolic formation from the mountain», have been implemented in other republics of the region - Turkmenistan, Kirghizia. All of them slowly changed the semantics of the new signs of statehood. With the help of specially formed collectives, the complex esoteric motifs that appeared in the symbolic expanses of the countries in the early 1990s were gradually replaced by the associative symbolism (cotton, ears, book, mountain outline, etc.) that characterized the Soviet heraldic tradition.

The most active search for forms of a new symbolic presentation of state sovereignty of the countries of the region unfolded in the Republic of Kazakhstan.

On December 10, 1991, the Kazakh SSR was renamed the Republic of Kazakhstan. And on December 16, 1991, Kazakhstan declared its independence.

After the collapse of the USSR, in Kazakhstan tenders were announced for projects of new national symbols, which received 453 variants of the flag and 245 sketches of the coat of arms ${ }^{10}$. On June 4, 1992, the Verkhovna Rada of the Republic of Kazakhstan approved laws on the state emblem and flag. Their semantics were radically different from the Soviet ones and were built on the combination of gold and blue with the motives of the sun's rays. We will add that, the symbolic complex of attribution of the Republic of

\footnotetext{
${ }^{10} \mathrm{Ibid}$
} 
Kazakhstan is the result of complex collective work, which clearly reflected on its conceptual foundations and aesthetic manifestations.

Summarizing the overview of the Central Asian region, we note that the formation of symbolic attribution complexes in its territory followed the model from above. At the same time, being the result of the author's developments, the new symbols of state sovereignty fully retained their loyalty to the Soviet heraldic style (except Kazakhstan). Thus, state symbolism in the Central Asian republics did not become a detonator of systemic changes, but only a reflection of them.

\section{State symbols as a reflection of the political order in post-totalitarian Belarus and Russia: lessons for Ukraine}

Particular attention should be paid to the role of national symbols in the formation of new political regimes in Belarus and the Russian Federation.

The history of the symbolic self-determination of Belarus was extremely dramatic. On July 27, 1990, the Supreme Council of the BSSR adopted a Declaration of State Sovereignty following a heated political debate that was ongoing in the Parliament. After the August events of 1991, it was decided to grant the document the status of a constitutional law. On the same day, on August 25, 1991, a resolution was issued to suspend the Communist Party of Belarus. And on September 19, 1991, the Belarusian Soviet Socialist Republic was renamed into the Republic of Belarus and the national symbols were changed ${ }^{11}$. The independent state of Belarus has received a new coat of arms and flag. The semantics of these symbols were based on the historical traditions of the Belarusian territorial heraldry, which is genetically related to the heraldic systems of the Grand Duchy of Lithuania and the Commonwealth. It was built on the traditional Belorussian culture of red and white color and the symbolic figure of the rider Pogoni. On March 15, 1994, the transformations that took place in the symbolic space of Belarus were enshrined in its Basic Law.

However, the political changes that followed the 1994 presidential election, following which President Lukashenko held the office of head of state, have become more active in trying to return Soviet-era symbols to the country's civic symbolism. A campaign to discredit the revived national symbolism as one that embodied the collaborative movement on the lands of Belarus during the period of German-fascist occupation (1941-1944) began).

11 О государственном флаге республики Беларусь: Закон Республики Беларусь от 19 сентября 1991 г. № 1090-ХІІ. Ведомости Верховного Совета Республики Беларусь. 1991. № 30. Ст. 493; Об утверждении эталона Государственного герба Республики Беларусь и Положения о Государственном гербе Республики Беларусь: Постановление Верховного Совета Республики Беларусь от 10 декабря 1991 г. № 1294-XII. Ведомости Верховного Совета Республики Беларусь. 1992. № 1. Ст. 13. 
Given that traditional national symbols were negatively perceived by Belarusian society, in particular by veterans' organizations, and against the background of a rather indifferent attitude of the political establishment to the problems of state symbols, the newly elected President of the Republic made the decision to change the topic for national discussion. On May 14, 1995, at the initiative of the President, a referendum was held in Belarussia on granting the Russian language the status of a state language, approving new state flags and emblems, as well as supporting the actions of the head of state aimed at economic integration with the Russian Federation. On all issues, a positive decision was made and the traditional Belarusian state flag and coat of arms were deprived of the status of state one ${ }^{12}$. And on May 16, 1995, the white-red flag was removed from the roof of the Government House. According to eyewitnesses, the cloth was torn to shreds «for souvenirs». From this moment, the national bicolor and coat of arms of the pursuit is used by the democratic opposition of Belarus as symbols of the struggle against the Lukashenko regime. Thus, with the change of political regime, the former state symbols of the Republic of Belarus have become political.

According to A. Grechilo, in the conditions of frantic propaganda the results of the referendum were predicted ${ }^{13}$. On this basis, a presidential decree of June 7, 1995 approved new symbols, which are essentially modified symbols of the BSSR. Thus, Belarus became the only former USSR republic, which with a small correction restored the attributive complex of the Soviet era. With the approval of Presidential Decree No. 350 of 02.07.2002, the new text of the State Anthem of Belarus, which was still in existence in the wording of 1955, finally formed the basic triad of national symbols, and on July 5, 2004 the Law of the Republic of Belarus «On State Symbols of the Republic of Belarus» (No. 301-3), coat of arms and anthem have been finally confirmed.

Tectonic changes in the process of political transit in the 1990s and 2000s have undergone the civil symbolosphere of the Russian Federation. After all, it was influenced by two multi-vector trends, determined by the need to acquire its own identity on the one hand and the need to assure the succession of the status of a country - a geopolitical and geocultural leader on the other.

12 Об итогах голосования на республиканском референдуме 14 мая 1995 года: Сообщение Центральной комиссии Республики Беларусь по выборам и проведению республиканских референдумов. Центральная комиссия Республики Беларусь по выборам и проведению республиканских референдумов: веб-сайт. URL: http://www.rec.gov.by/refer/ref1995resdoc.html.

${ }^{13}$ Гречило А. Герби новопосталих держав. Пам'ятки Украӥни: Історія та культура. 2001. № 2. C. 168. 
The liberalization of the Soviet political regime, which took place in the late 1980s, helped to bring the issue of national Russian symbols to the epicenter of public debate. The fiercest debate has been around the new flag. Their participants were divided into three groups. Representatives of the first, the most radical, strongly advocated the need to revive the blackyellow-white flag with monarchical symbolism. The second group tended to abandon the Soviet symbols. However, the position that insisted on the restoration of the white-blue-red flag was won, since it was defined by most citizens as national. During the dramatic events of the August putsch, national Russian tricolor was widely used by forces opposed to the State Emergency Committee (SEC). On August 22, 1991 by the Decree of the Supreme Council of RSFSR «the historical flag of Russia» was recognized as «the official State Flag of the Russian Federation ${ }^{14}$. And as early as November 1, 1991, it was approved in the status of the state flag of the RSFSR at the legislative level ${ }^{15}$.

The end of 1991 was marked by another important change in the symbolic space of Russia: on December 25, 1991, the name «RSFSR» was legally changed to «Russian Federation».

If the new flag was organically incorporated into the civic symbolosphere of a democratic Russia, then the issue of the state emblem was rather difficult, which affected the timing of its setlement.

It is clear that with the acquisition of the new coat of arms radical changes come not only in the socio-cultural sphere, alleys and office. Firstly, the emblem of the RSFSR continued to be used after the renaming of the state itself on December 25, 1991, until May 1992, when a number of amendments was not made to the Constitution and Basic Law of the RSFSR. And only on December 6, 1993 «... with the aim of restoring the historical symbolism of the Russian statehood», as well as «bearing in mind that the State Emblem of the RSFSR lost its symbolic meaning», a fundamentally new heraldic concept was introduced by the Presidential Decree. The Decree stated: «1. The State Emblem of the Russian Federation is an image of a golden two-headed eagle placed on a red heraldic shield; above the eagle three historical crowns of Peter the Great (above the heads - two small and above them - one larger); in the paws of an eagle - the scepter and the state;

14 Об официальном признании и использовании Национального флага РСФСР: Постановление Верховного Совета РСФСР от 22 августа 1991 г. № 1627/I-I. Caŭm Конституции Российской Федерации. URL: http://constitution.garant.ru/history/.

${ }^{15}$ Об изменениях и дополнениях Конституции (Основного Закона) РСФСР: Закон РСФСР от 1 ноября 1991 г., принят пятым (внеочередным) Съездом народных депутатов PCФСР, (прекратил действие). Сайт Конституции Российской Федерации URL: http://constitution.garant.ru/history/ussr-rsfsr/1978/zakony/183125. 
on the chest of an eagle on a red shield is a rider striking with a spear. 2. Reproductions of the State Emblem of the Russian Federation in the onecolor variant, as well as its reproduction in the form of the main figure two-headed eagle are allowed $\gg{ }^{16}$.

However, this dramatic return to imperial discourse was not supported by all Russians. For example, in the debate that began in the late 1990s around the issue of state symbols, many supported the idea of returning to the symbolism of socialist Russia. On December 20, 2000, the Federal Constitutional Law «On the State Emblem of the Russian Federation» was promulgated, which put an end to disputes. The obvious imperial semantics of the Russian emblem in the official interpretation takes on the following meaning: the three crowns represent the sovereignty of both the entire Russian Federation and its constituent entities, and the scepter with the state holding the two-headed eagle in its paws symbolizes the state power and united state ${ }^{17}$. Thus, in general, the coat of arms of the Russian Federation is a reflection of the foundations of the political culture of Russian society, the basic components of which are the cult of great power, piety before the authorities, etc.

Indicative in terms of the characteristics of those processes that take place in the civic symbolism of post-Soviet Russia, is also the story of her acquisition of a new anthem. Today's State Anthem of the Russian Federation - the resuscitated Soviet anthem for the music of Alekdandr Alekdandrov - was approved on December 8, 2000 by a separate Federal Constitutional Law signed by the newly elected head of state V. Putin ${ }^{18}$.

The previous State Anthem of the Russian Federation (1990 - 2000) M. Glinka's «Patriotic Song», which did not receive poems as a state symbol - failed to gain unquestionable popularity in the general public.

With the change of leadership of the country in 2000, which marked the return to the ideological discourse of the theme of national patriotism and the continuity of traditions of strong imperial statehood, the question of changing the main musical symbol of the country was put on the agenda. Based on the data of many sociological polls and noting the low popularity of the «Patriotic Song», the State Duma of the Russian Federation adopts a draft of the law «On the National Anthem of the Russian Federation» on

${ }^{16}$ О Государсвенном гербе РФ: Указ Президента РФ № 2050 от 30 ноября 1993 г. Официальный сайт Президента России. URL: http://president.kremlin.ru.

17 Государсвенная символика РФ. Государственная символика: веб-сайт. URL: http://www.statesymbol.ru.

${ }^{18}$ О Государственном гимне Российской Федерации: Федеральный конституционный Закон №3-ФКЗ от 8 декабря 2000 г. Официальный сайт Президента России. URL: http://document.kremlin.ru/doc.asp? $\mathrm{ID}=5163 \& \mathrm{PSC}=1 \& \mathrm{PT}=3 \& \mathrm{Page}=5$. 
March 10, 1999 in the first, and December 8, 2000 - in the third, final reading. On December 20, 2000, the law was overwhelmingly approved by the Federation Council: the music of A. Aleksandrov (USSR anthem) was approved as the tune of the anthem, and poems were sought. On December 25, 2000, Putin created a working group to consider proposals for the anthem text. In the period from December 2000 to February 2001, 5 drafts were tabled in the country's parliament on the subject. Among them was a poem by S. Mikhalkov and G. El-Registan. This modernized version of the Soviet anthem was supported by Putin. It was adopted as the text of the official anthem of the Russian Federation on March 7, 2001.

Summarizing the history of the formation of the symbolic complex of attribution of the Russian Federation, it can be noted that it is a rather eclectic formation, consisting of fragments of various political discourses (monarchical, Soviet, national-patriotic), characteristic of post-Soviet Russia and explicitly amateurish and the geopolitical domination of Putin's Russia.

\section{CONCLUSIONS}

Familiarity with the main milestones of the formation of new attributive complexes in the new post-Soviet countries allows us to make some generalizations about the place and role of state symbols in the processes of independence and statehood and to identify, on this basis, the relationship between a particular model of formation of a symbolic complex, the attribution of its symbolic complex, filling and specifics of newly created political regimes.

So, first, according to the functional load in the processes of political transit several varieties of symbolic attribution complexes (SAC) can be distinguished, namely:

a) SAC, whose constituents are symbols - catalysts, where the latter can be fully considered the basis of the symbolic matrix of political transformations (Baltic Republics, Moldova, Georgia). We will add that the main functions of the symbols - catalysts for the transition period are political mobilization and integration of public communities.

b) SAC, whose constituents are symbols - retainers, which act as reverberators of already made systemic transformations (Central Asian countries). This model of SAC formation foresees, first of all, the reliance on the state symbolism of the function of legitimizing the newly emerging political regime of authoritarian nature.

c) SAC, the dominant component of which is represented by symbols indicators. They serve as markers of social inquiry in the market of spiritual and ideological production and perform, above all, the function of political 
identification (Belarus, the Russian Federation, partly the republics of the Caucasus and the Transcaucasia).

Second, the form and semantic load of the SAC formed in the post-Soviet space can be divided into those based on:

a) the return of state symbols of the pre-Soviet period (Baltic countries, Russian Federation (in part));

b) national symbols and national symbols of the postwar period (Caucasus and Transcaucasian countries, Moldova (partially));

c) for symbols - copyright work (Central Asian countries);

d) for partial resuscitation of Soviet heraldic stylistics (Russian Federation, Belarus).

Finally, let's note the following. The emergence of new independent states on the political map always requires a radical review of the foundations of their symbolic attribution complexes. As the experience of the republics of the former USSR showed, the ways and dramaturgy of the SAC formation are clearly linked to political and socio-cultural factors. Thus, in the European and Caucasian countries of the post-Soviet space, where today democratic and hybrid regimes were formed, despite the notable enough ideological resistance from the party nomenclature, the turn to historic national symbols took place in the process of independence. On the contrary, the authoritarian republics of Central Asia and Kazakhstan have constructed SACs of their sovereignty on wholly newly created (though not beyond national or cultural) symbols. And the heraldic-semantic and conceptual eclecticism of the SAC of the Russian Federation and Belarus clearly indicates the main tendencies of political development of these countries at the present stage.

Equally revealing was the process of rebuilding the symbolic complex of Ukraine's attribution. Given that in today's political realities and geopolitical challenges, these issues need to be thoroughly considered and deserve some basic research ${ }^{19}$, let us note only that the systemic changes that our country has been experiencing in recent years were also reflected in the content load of the symbolic attribution complex, which went from the symbols of the liberation struggle through a period of emblematic official protocols to the transformation of the Ukrainian society into an instrument of consolidation of political nation. All this reinforces our hopes for the irreversibility of the results of democratic transit that our society has embarked on

${ }^{19}$ Мамонтова Е. В. Державний протокол та церемоніал як символічний інструмент забезпечення процесу публічної комунікації: витоки, структура, нормативноорганізаційні засади: монографія. Одеса: Друкарський дім, 2011. 480 с. 


\section{SUMMARY}

The work on the material of the countries of the former Soviet Union shows the place and role of state symbols in the processes of independence and statehood. The interdependence of political and socio-cultural determinants of social development is determined on the basis of identification and comparison of characteristic features of symbolic selfdetermination of the Baltic countries, Caucasus, Central Asia, Moldova, Belarus, and the Russian Federation. The peculiarities of the symbolic attribution of state sovereignty as a factor of political transit are revealed and an assessment of its state-building potential is given. The main sources of symbolization of the post-totalitarian era are outlined: national and spiritual symbolism; state (imperial) symbolism of the pre-Soviet period; republican symbols of the postwar period; resuscitation of Soviet heraldic stylistics; artificial symbolism as a result of copyright. The relationship between functional and semantic loading of state symbols with the trajectory of political transit is shown. The specific character of the retainer symbols, which act as a retractor of the already implemented systemic transformations and provide the function of legitimizing the newly emerging political regime of authoritarian character, is outlined. Characteristics of symbols - indicators that perform the function of political identification and serve as markers of social inquiry in the market of spiritual and ideological production in hybrid modes are characterized. It is proved that to provide a democratic vector of political transit symbols - catalysts are capable, which in the processes of state formation perform the function of political mobilization and integration of public communities. It is argued that the irreversibility of democratic change can be ensured not only by the development of democratic institutions and formal perceptions of democratic rules and procedures, but also by the consolidation of democratic values at the level of the cultural code. The last task can be realized only under the influence of cultural and value factors, among which the important place belongs to symbolism.

\section{REFERENCES}

1. Государсвенная символика РФ. Государственная символика: веб-сайm. URL: http://www.statesymbol.ru.

2. Государсвенный флаг Республики Молдова: Положение о Государственном флаге, утвержденное Постановлением Парламента № 17-XII от 12 мая 1990 года). Президентура Республики Молдова: вебcaüm. URL: http://www.president.md/simb.php?lang=rus.

3. Гречило А. Герби новопосталих держав. Пам'ятки Украӥни: Історія та культура. 2001. № 2. С. 162-167.

4. Гречило А. Символи нових незалежних держав. Пам'ятки України: Історія та культура. 2001. № 4. С. 135-141. 
5. Мамонтова Е. В. Державний протокол та церемоніал як символічний інструмент забезпечення процесу публічної комунікації: витоки, структура, нормативно-організаційні засади: монографія. Одеса: Друкарський дім, 2011. 480 с.

6. О Государсвенном гербе РФ: Указ Президента РФ № 2050 от 30 ноября 1993 г. Официальный сайт Президента России. URL: http://president.kremlin.ru.

7. О Государственном гимне Республики Молдова: Закон РМ №571-XIII от 22 июля 1995 года. Президентура Республики Молдова: веб-сайт. URL: http://www.president.md/simb.php?lang=rus.

8. О Государственном гимне Российской Федераџии: Федеральный конституционный Закон №3-ФКЗ от 8 декабря 2000 г. Офищиальный сайт Президента России. URL: http://document.kremlin.ru/ doc. asp? ID $=5163 \& \mathrm{PSC}=1 \& \mathrm{PT}=3 \& \mathrm{Page}=5$.

9. О государственном флаге республики Беларусь: Закон Республики Беларусь от 19 сентября 1991 г. № 1090-XII. Ведомости Верховного Совета Республики Беларусь. 1991. № 30. Ст. 493.

10. О Государственном флаге Республики Узбекистан: Закон Республики Узбекистан. Правда Востока. 1991. 27 ноября. С. 1.

11. Об изменениях и дополнениях Конституции (Основного Закона) РСФСР: Закон РСФСР от 1 ноября 1991 г., принят пятым (внеочередным) Съездом народных депутатов РСФСР, (прекратил действие). Сайт Конституции Российской Федеращии. URL: http://constitution.garant.ru/history/ussr-rsfsr/1978/zakony/183125.

12. Об итогах голосования на республиканском референдуме 14 мая 1995 года: Сообщение Центральной комиссии Республики Беларусь по выборам и проведению республиканских референдумов. Центральная комиссия Республики Беларусь по выборам и проведению республиканских референдумов: веб-сайт. URL: http://www.rec.gov.by/refer/ref1995resdoc.html.

13. Об официальном признании и использовании Национального флага РСФСР: Постановление Верховного Совета РСФСР от 22 августа 1991 г. № 1627/I-I. Сайт Конституции Российской Федерации. URL: http://constitution.garant.ru/history/.

14. Об утверждении эталона Государственного герба Республики Беларусь и Положения о Государственном гербе Республики Беларусь: Постановление Верховного Совета Республики Беларусь от 10 декабря 1991 г. № 1294-XII. Ведомости Верховного Совета Республики Беларусь. 1992. № 1. Ст. 13.

15. Положение о Государственном гербе, утвержденное Законом Республики Молдова № 337-XII от 3 ноября 1990 года. Президентура 
Республики Молдова: веб-сайт. URL: http://www.president.md/ simb.php?lang=rus.

16. Про Державний герб Республики Молдова: Закон РМ № 337XII от 3 ноября 1990 г. Президентура Республики Молдова: веб-сайт. URL: http://www.president.md/simb.php?lang=rus.

17. Про изменение статей 168 та 169 Конституции Литовськой ССР: Закон Литовской РСР от 18.11.1988 г. Советская Литва. 1990. 19 ноября.

18. Цугунян М. 3 історії герба та прапора республіки Вірменії. Знак. 1994. № 7. С. 9.

Information about the author: Mamontova E. V., Doctor of Political Sciences, Professor, Professor at the Department of Political Theories of the National University «Odessa Law Academy» 2, Academichna str., Odesa, 65009, Ukraine 